\title{
KOEVOLUSI RADIO BERITA RRI PRO3 PADA PROGRAM INDONESIA MENYAPA
}

\author{
Sri Ulya Suskarwati \\ Institut Komunikasi dan Bisnis LSPR, Jakarta. \\ sri.us@1spr.edu \\ Diajukan: 19-10-2019; Direview: 30-10-2019; Diterima: 09-12-2019;
}

\begin{abstract}
Competition between radio media is inevitable due to emergence of the internet. This was also experienced by Radio Republik Indonesia Programa 3 or RRI Pro3 by changing the news content from FM 88.8 MHz to RRI Net. This research aim to describe the transformation of news content by RRI Pro3. The author uses the coevolution concept of Roger Fidler's Mediamorphosis Theory, to direct understanding the transformation of form of communication media. The approach used is qualitative with a constructivist paradigm. Data collection techniques through interviews, observation, and documentation. The unit of research analysis is the 'Indonesia Menyapa' program. The results was found that, listeners befits to watch television programs in the format of radio content that they like. There is new thinking about news content, which initially took the form of an imaginative auditive, then was changed to visual radio content.
\end{abstract}

Keywords: News Content, Visual Radio, Mediamorphosis, Roger Fidler

\begin{abstract}
Abstrak
Persaingan antara media radio tidak bisa dihindari akibat munculnya internet. Hal tersebut dialami juga oleh Radio Republik Indonesia Programa Tiga atau RRI Pro3 dengan mengubah konten berita dari FM 88,8 MHz ke RRI Net. Penelitian ini bertujuan untuk mendeskripsikan transformasi konten berita oleh RRI Pro3. Penulis menggunakan konsep koevolusi dari teori Mediamorfosis Roger Fidler, untuk mengarahkan pemahaman transformasi bentuk media komunikasi. Pendekatan yang digunakan kualitatif dengan paradigma konstruktivis. Teknik pengumpulan data melalui wawancara, observasi, dan dokumentasi. Unit analisis penelitian adalah program 'Indonesia Menyapa'. Hasilnya ditemukan bahwa, pendengar RRI Pro3 layaknya menonton program televisi dalam format konten radio yang ia sukai. Terdapat pemikiran baru tentang konten berita, yang awalnya berbentuk auditif imajinatif, kemudian diubah menjadi konten radio visual.
\end{abstract}

Kata Kunci: Konten Berita, Radio Visual, Mediamorfosis, Roger Fidler

\section{PENDAHULUAN}

$R$ adio is the theater of mind. Ungkapan ini mulai terkikis seiring perkembangan teknologi komunikasi yang melaju pesat. Medium komunikasi massa yang dulunya menciptakan imajinasi subyektif pendengar ini, perlahan namun pasti mengikuti perubahan jaman.
Siaran radio yang awalnya bersumber pada materi siaran auditif semata, kini makin variatif. Tidak hanya memanjakan audiens melalui ruang dengar, namun terasa makin dekat dengan berbagai siaran radio yang dapat disajikan secara visual dan interaktif. Perubahan ini, adalah fenomena nyata sebagai usahanya untuk bertahan. 
Radio memiliki kekuatan magis dalam menyampaikan pesan yang mampu membangun imajinasi pendengar untuk larut dalam ikatan emosional yang tidak bisa didefinisikan. Imajinasi mengacu pada resepsi pesan yang disampaikan melalui suara dengan visualisasi makna yang hadir pada masing-masing audiens (Geller, 2011). Radio memiliki kemampuan menyampaikan pesan dengan membangun kedekatan atau personal relationship antara penyiar dan pendengar. Siaran radio yang disajikan penyiar 'terdengar' sebagai one-to-one relationship, berkomunikasi dengan audiens sebagai individu bukan sebagai mass audience (Ahern, 2011).

Menyesuaikan format konten dengan target pendengar yang disasar memang menjadi cara jitu dalam mengemas sebuah informasi yang sesuai dengan kebutuhan pendengarnya. Seperti konten berita pada Radio KBR, Sindo Trijaya, Elshinta, Jak FM dan Gen FM. Berita dikemas dengan 'bahasa radio' yang singkat, padat, dan jelas (Siahaan, 2016).

Keempat radio tersebut diketahui tidak berpatokan pada kualitas vokal dan warna suara tertentu dalam presentasi siaran berita. Penekanannya terletak pada jenis berita hard news, maka umumnya keempat radio menerapkan gaya presentasi siaran dengan memperdengarkan suara berbicara cepat, berintonasi dan dengan artikulasi yang jelas.

Penulis mengamati bahwa hingga saat ini radio siaran masih tetap bertahan, kreativitas konten yang variatif menjadi kunci utama untuk menjaga eksistensinya. Gempuran persaingan program televisi hingga produktivitas para content creator yang mewarnai era new media saat ini, memaksa radio programmer untuk beradaptasi dengan perkembangan teknologi komunikasi.

Konten radio yang diproduksi sebagai program acara, diantaranya comedians, popular dance bands and singers, sports events, politicians, news broadcasts, dan daytime 'soap opera'. Masingmasing konten tersebut dikemas dengan tujuan untuk mendekatkan radio kepada pendengarnya (Dennis, DeFleur, 2010). Konten inilah yang terus berkembang sebagai kreativitas radio programmer yang memanfaatkan kemajuan teknologi komunikasi sebagai bentuk adaptasi di era media baru.

Adaptasi ini diistilahkan sebagai transformasi. Konsep ini merupakan proses yang kompleks sebagai rangkaian evolusi spesies. Bentuk-bentuk baru dari media yang sukses, tidak muncul begitu saja tanpa asal usul. Keseluruhan proses itu membutuhkan rantai penghubung dengan masa lalu. Transformasi media ini adalah rangkaian bentuk media di masa lalu, saat ini, dan masa yang akan datang, sebagai mediamorfosis (Fidler, 1997).

Kajian mediamorfosis memperlihatkan bahwa munculnya media komunikasi baru tidak lantas mematikan yang lama. Budaya komunikasi tradisional di Afrika tidak hilang dengan adanya media digital. Keduanya berkonvergensi sebagai bentuk media komunikasi yang adaptif (Nwammuo, 2011).

Pemikiran Fidler juga membangun kajian dalam beberapa media yang terintegrasi, seperti cetak, radio, televisi dan internet. Konvergensi beberapa media komunikasi ini memaksa jurnalis memproduksi pesan ke dalam media berbasis audio, video dan teks (Avilés \& Carvajal, 2008).

Kedua penelitian di atas memperlihatkan bahwa mediamorfosis mengakibatkan beberapa bentuk media komunikasi yang menyatu. Selanjutnya, penelitian di Radio KBR, Sindo Trijaya, Elshinta, Jak FM dan Gen FM, memperlihatkan format berita dengan konsep jurnalistik konvensional. Konten didalamnya didistribusikan secara auditif semata.

Dalam penelitian ini, evolusi siaran radio yang dikenal auditif dapat dikonsumsi dalam bentuk pesan yang adaptif dengan perkembangan media komunikasi. Radio Republik Indonesia Programa Tiga (penulisan berikutnya disingkat dengan RRI Pro3), adalah salah satu radio siaran yang menurut pengamatan penulis melakukan adaptasi teknologi komunikasi di era media baru. RRI Pro3 sebagai siaran Jaringan Berita Nasional menyajikan berita dan informasi. Lembaga Penyiaran Publik ini tidak hanya memproduksi konten secara auditif pada gelombang FM 88.8 MHz, namun juga konten radio visual yang dapat diakses melalui aplikasi 
RRI PLAY, XMedia, Usee TV, Ninmedia TV, dan RRI Net.

Dalam penelitian ini, penulis ingin mengkonstruksi bentuk transformasi siaran berita di RRI Pro3. Fokus kajian dalam penelitian akan menyoroti transformasi konten berita pada periode prime time pagi. Konten yang dimaksud adalah siaran 'Indonesia Menyapa', disajikan setiap hari Senin hingga Sabtu, pukul $07.00-09.00$ WIB. Kajian transformasi konten ini berlandaskan teori mediamorfosis Roger Fidler dengan konsep koevolusi.

\section{LITERATUR DAN METODE PENELITIAN}

\section{Siaran Radio dan Radio Siaran}

Siaran radio pada umumnya dikenal sebagai konten atau program radio. Terdiri dari siaran kata (talk), siaran musik (music) dan siaran iklan (advertising). Konten tersebut dikelola dengan baik agar jumlah dan loyalitas pendengar sesuai dengan target yang diinginkan. Target pendengar ini tentunya akan menjadi sasaran dalam perolehan pendapatan dari pemasang iklan. Menurut Picard (1989), perusahaan media memproduksi konten kepada audiens dan secara bersamaan memproduksi dan memasarkan audiens kepada pengiklan (McQuail, 2011).

Selanjutnya dikatakan bahwa mempelajari konten media dengan cara yang sistematis berasal dari ketertarikan terhadap efek potensial komunikasi massa dan keinginan untuk memahami daya tariknya bagi khalayak. Studi awal mengenai konten mencerminkan perhatian terhadap masalah sosial yang dihubungkan dengan media. Namun berangsur-angsur diperluas meliputi berita, informasi dan konten hiburan lainnya.

Sementara itu, radio siaran adalah stasiun penyiaran yang dituntut untuk memiliki kreativitas dalam menghasilkan berbagai program yang menarik. Program tersebut dikelompokkan menjadi (1) program informasi, dan (2) program hiburan (Morissan, 2008). Beragam program ini diproduksi oleh radio siaran untuk menjangkau pasar media dengan tujuan bertahan dalam industri media yang kompetitif.
Stasiun radio penyiaran milik negara yang beroperasi di Indonesia adalah RRI Pro3. Penelitian ini mengkaji secara mendalam program unggulan Indonesia Menyapa, sebagai siaran radio yang penulis asumsikan melakukan transformasi konten. Hal ini dilakukan sebagai bentuk adaptasi untuk mempertahankan keberadaannya diera perkembangan teknologi komunikasi saat ini.

\section{Sifat dan Karakteristik Radio}

Radio dikenal sebagai media massa elektronik dengan konten yang bersumber pada suara. Dikenal sebagai 'blind medium', karena audiens tidak dapat 'melihat' pesan yang ditransmisikan. Salah satu cara radio menuntun audiens-nya adalah penggambaran pesan melalui bahasa yang dituturkan penyiar. Bahasa yang dapat menciptakan 'kedekatan' pengirim pesan dan penerimanya (Crisell, 1994).

Sementara itu, daya tarik radio bersumber pada suara, penggunaan yang lebih mudah dan dapat dibawa kemana-mana. Produksi radio juga lebih mudah, fleksibel dan relatif lebih murah dibandingkan televisi. Radio berpotensi partisipasi dua arah, penggunaannya akrab dan bersifat personal. Konten radio juga dinilai beragam, namun lebih banyak bermain musik. Karakteristik radio dipolakan sebagai distribusi terpusat dimana radio memegang peranan sebagai penyedia konten (McQuail, 2011).

Radio diketahui bersifat lokal (radio is local), menjangkau wilayah-wilayah tertentu (radio is fragmented), format dankonten radio menjadi lebih khusus (radio is specialized). Selain itu, kemasan program radio menjadi lebih personal (radio is personal) dan dapat dinikmati 'anywhere at anytime' sambil melakukan kegiatan lainnya (radio is mobile) (Stanley J, 2019). Radio juga dikatakan media selintas, sehingga disiarkan dengan konsep repetisi agar pesan dapat diterima audiens. Hal ini disebabkan pula oleh keterbatasan radio yang tidak memungkinkan audiens melakukan pause atau rewind informasi yang telah disampaikan, karena itu bahasa penyiar harus lebih mudah dimengerti (Lynne, Brian, Philippe, 2005). 


\section{Radio dalam Perkembangan Teknologi di Era Media Baru}

Kemunculan teknologi komunikasi baru mengembangkan infrastruktur industri radio seperti iPod, Podcasting dan On-Demand Radio. Media ini mentransmisikan konten yang serupa dengan radio melalui internet dan broadband (Vivian, 2008). Tahun 2000, juga muncul satellite radio sebagai radio berbayar. Signal radio dipancarkan satelit dan diterima melalui sistem berlangganan. Kekuatan dari radio satelit ini pada jumlah radio channel yang dapat diakses. Ratusan radio channel sebagian besar tidak menyiarkan iklan, dapat dikonsumsi oleh pelanggan di seluruh dunia (Dennis \& DeFleur, 2010).

Selanjutnya muncul Internet Radio, HD Radio dan Digital Radio. Sesuai dengan namanya, internet radio memanfaatkan internet sebagai alat distribusi kepada audiens-nya yang dikenal dengan net radio, e-radio dan streaming radio. Sedangkan HD (High Definition) Radio menghubungkan signal analog dengan signal digital. Kekuatan media pada kualitas audio yang lebih baik, dibandingkan radio AM dan FM. Demikian pula dengan digital radio. Hanya saja, digital radio mengharuskan audiens mempersiapkan perangkat radio berbasis digital.

Media baru pada dasarnya memberikan peluang keuntungan, sekaligus pesaing bagi media massa yang dekat dengan media lama. Meskipun tidak secara langsung mendukung komunikasi massa, namun media baru telah memperluas lingkungan media dan menjembatani komunikasi publik dan pribadi. Internet dicirikan sebagai teknologi berbasis komputer, karakternya hibrida, tidak berdedikasi, fleksibel dan berpotensi interaktif. Ciri lainnya adalah berfungsi publik dan privat, peraturan yang tidak ketat, kesalingterhubungan, tidak tergantung lokasi, dapat diakses individu, serta menjadi media komunikasi massa dan pribadi (McQuail, 2011).

Internet merupakan titik pusat konvergensi teknologi dan sistem global yang terhubung dengan jaringan private, public, academic, business dan pemerintahan, serta menghubungkan para pengguna di dunia. Internet telah menjadi perantara munculnya media baru. Kemampuannya memediasi kreativitas pembuat konten, seperti video dan musik menyemarakkan produksi media ini. Khalayak seperti ini disebut user-generated content (UGC). Konten lainnya dalam media baru adalah social media site (social networking site/SNS) yakni media jaringan sebagai media interaksi berbentuk informasi teks, foto atau video. Contohnya Facebook, YouTube, Instagram. Google+, Twitter, LinkedIn, dan sebagainya (Turow, 2014).

\section{Koevolusi dalam Teori Mediamorfosis}

Fidler mendefinisikan mediamorfosis sebagai transformasi media komunikasi yang terjadi akibat interplay rumit dari berbagai kebutuhan, tekanan kompetitif dan politis, serta inovasi-inovasi sosial dan teknologi. Mediamorfosis bukanlah sekadar teori sebagai cara berpikir terpadu tentang evolusi teknologi media komunikasi. Mediamorfosis mendorong untuk memahami semua bentuk sebagai bagian dari sebuah sistem yang saling terkait dan mencatat berbagai kesamaan dan hubungan yang ada antara bentuk-bentuk yang muncul di masa lalu (past), masa kini (present), dan yang sedang dalam proses kemunculannya (emerging forms). Mempelajari sistem komunikasi secara menyeluruh, menggambarkan bahwa media baru tidak muncul begitu lama. Ketika bentukbentuk media komunikasi yang lebih baru muncul, bentuk-bentuk yang terdahulu biasanya tidak mati, namun terus berkembang dan beradaptasi (Fidler, 1997).

Lebih lanjut dikatakan, bahwa setiap bentuk komunikasi yang baru, merupakan pengembangan lebih lanjut dari bentuk yang lebih dulu muncul. Pengembangan ini, memungkinkan perubahan bentuk komunikasi yang berbeda dari bentuk sebelumnya. Transformasi merupakan proses kompleks sebagai rangkaian evolusi spesies. Bentuk-bentuk baru dari media yang sukses, tidak muncul begitu saja tanpa asal usul. Keseluruhan proses itu membutuhkan rantai penghubung dengan masa lalu.

Fidler juga menguraikan transformasi media komunikasi berasal dari tiga konsep dasar, yaitu: koevolusi, konvergensi dan kompleksitas. Ketiga 
konsep dasar ini membentuk perubahan medium komunikasi akibat evolusi teknologi komunikasi. Pemahaman mengenai teori ini diperdalam dengan mengelompokkan bentuk-bentuk komunikasi yang ada berdasarkan ciri-ciri dominan pada domaindomain komunikasi yang akan terus berkembang. Fidler mengelompokkannya ke dalam domain interpersonal, penyiaran dan dokumen.

Domain interpersonal meliputi bentuk-bentuk komunikasi yang melibatkan informasi dua arah. Sedangkan domain penyiaran dinyatakan sebagai komunikasi yang pasif dan minim interaksi. Hampir semua informasi yang disampaikan diproses oleh medium perantara. Domain dokumen merupakan informasi yang disampaikan berupa tulisan dan visual terstruktur melalui media yang dapat dibawa, misalnya: koran, majalah dan buku, termasuk informasi yang tersimpan dalam jaringan komputer. Pada perkembangannya, dokumen hiperteks diciptakan dalam era digital. Teknologi ini kemudian memungkinkan informasi dari berbagai halaman saling terhubung (link).

Koevolusi dijabarkan Fidler sebagai sebuah bentuk komunikasi yang tersusun dalam sistem komunikasi manusia. Sistem ini tidak dapat dipisahkan satu sama lain dalam suatu kebudayaan. Begitu muncul dan berkembang sebuah bentuk baru dalam suatu periode waktu tertentu hingga tingkatan yang beraneka ragam, akan memengaruhi perkembangan setiap bentuk lain yang ada.

Demikian pula dengan perubahan-perubahan bentuk media komunikasi yang ada. Fidler menggambarkan bentuk-bentuk khusus media, sama halnya dengan spesies dalam siklus kehidupan, dari kelahiran hingga pada akhirnya mati dan benar-benar punah. Namun sebagian besar sifat dasarnya akan selalu tetap menjadi bagian dari sistem. Sama seperti ciri-ciri biologis yang diturunkan dari satu generasi ke generasi berikutnya melalui kode-kode genetik, sifat-sifat dasar media diwujudkan dan diteruskan melalui kode-kode komunikator yang disebut sebagai bahasa.

Konsep koevolusi ini akan menjadi landasan khusus dalam mengkonstruksi transformasi konten radio. Melihat perkembangan bentuk konten dan sifat dasar yang menetap sebagai ciri dari sebuah siaran radio.

Fidler juga menguraikan konsep konvergensi dalam mediamorfosis. Sebuah konsep yang secara garis besar merupakan penyatuan berbagai macam teknologi dan bentuk media yang hadir secara bersamaan. Konvergensi ini pada akhirnya akan mengarah pada bentuk-bentuk yang dikenal sebagai komunikasi multimedia.

Selanjutnya, konsep ketiga dari mediamorfosis yang diurai Fidler adalah kompleksitas. Konsep ini merupakan sebuah kondisi yang 'memaksa' terjadinya perubahan. Selama masa perubahan besar, sebagai masa yang kita alami saat ini dimana sekeliling kita mungkin tampak berada dalam kondisi kacau atau chaos. Chaos inilah yang kemudian menjadi komponen penting perubahan.

Konsep mediamorfosis yang kedua dan ketiga merupakan penjabaran semata sebagai bentuk pemahaman, namun tidak menjadi fokus dan landasan dalam penelitian ini.

\section{Metode Penelitian}

Penelitian ini menggunakan paradigma konstruktivis. Dalam paradigma ini, kalangan konstruktivis berpegang teguh pada pandangan bahwa pengetahuan dan kebenaran objektif merupakan hasil perspektif. Pengetahuan dan kebenaran diciptakan, tidak ditemukan oleh pikiran. Paradigma ini menekankan pada karakter realitas yang jamak dan lentur. Jamak dalam arti bahwa realitas dapat diungkapkan dalam beragam sistem simbol dan bahasa. Lentur dalam pengertian bahwa realitas dibentuk sesuai dengan tindakantindakan yang dilakukan oleh para pelaku sesuai tujuannya (Denzin \& Lincoln, 2009).

Adapun metode penelitian yang digunakan adalah metode penelitian kualitatif. Proses penelitian kualitatif ini melibatkan upaya-upaya penting, sepertimengajukan pertanyaan-pertanyaan dan prosedur-prosedur, mengumpulkan data yang spesifik dari para partisipan, menganalisis data secara induktif mulai dari tema-tema yang khusus ke tema-tema umum, dan menafsirkan makna datadata (Creswell, 2010). 
Sementara itu, unit analisis dalam penelitian ini mengacu pada landasan konsep koevolusi dalam teori mediamorfosis. Artinya, mengkonstruksi perkembangan konten RRI Pro3 khususnya program acara Indonesia Menyapa yang disajikan di masa lalu (past), masa kini (present), dan yang sedang dalam proses kemunculannya (emerging forms). Pada analisis pertama, penulis melakukan kajian terkait dengan konten radio sebagai media auditif. Analisis ini menekankan pada produksi program radio yang bersumber pada audio semata. Kajian kedua mengurai pemahaman mengenai perkembangan konten radio yang bersumber pada audio, visual dan teks. Selanjutnya, analisis ketiga merupakan kajian konten radio yang diprediksi berkembang di masa yang akan datang.

\section{TEMUAN DAN DISKUSI}

Berdasarkan hasil penelitian yang dilakukan pada RRI Pro3, penulis menguraikan perubahan konten sebagai adaptasi radio siaran dalam industri media. Perubahan ini dikelompokkan berdasarkan landasan teori mediamorfosis dengan konsep koevolusi sebagai proses berkesinambungan dari masa lalu, masa kini dan di masa yang akan datang. Konsep ini mengkonstruksi perubahan masing-masing kelompok tersebut, dan memaknai sifat dasar sebagai ciri yang tetap melekat pada transformasi konten dalam radio.

\section{Konten Media sebagai Siaran Radio Auditif}

Kemunculan konten RRI Pro3 disajikan untuk telinga pendengar. Menurut Kepala Pusat Pemberitaan RRI Widhie Kurniawan, konten media disajikan RRI Pro3 idealnya hanya memenuhi kebutuhan pendengarnya. Siaran radio khususnya Jaringan Berita Nasional, tersaji dengan konsep menemani. Artinya, para pendengar dapat mengonsumsi konten berita sambil melakukan kegiatan lainnya.

Berdasarkan tugas pokok sebagai Lembaga Penyiaran Publik (LPP), RRI Pro3 merupakan pusat siaran jaringan berita nasional dan kantor berita radio. Hadir sebagai sumber informasi terpercaya sesuai prinsip lembaga penyiaran publik yang menjunjung nilai-nilai standar penyiaran. Siaran bersifat independen dan netral, harus memihak pada kebenaran, siaran memberi pemahaman, mengurangi ketidakpastian, berpedoman pada Pancasila, UUD 1945 dan kebenaran, serta peraturan yang lainnya. Siaran juga harus memihak hanya kepada kepentingan Negara Kesatuan Republik Indonesia (NKRI), harus menjaga persatuan, kesatuan dan kedaulatan NKRI (www.rri.co.id).

Khususnya mengkaji program siaran Indonesia Menyapa yang hadir pada gelombang FM 88.8 $\mathrm{MHz}$, dipahami sebagai konten media yang bersumber pada audio semata mendistribusikan berita dari suara penyiar ke telinga pendengar. Produser Indonesia Menyapa Wirda Yulita Putri, mengatakan bahwa kreativitas tim produksi dalam mengemas berita ditujukan untuk memberikan informasi yang sesuai dengan fakta. Penyiar, Reporter, Produser, Pengarah Acara, Operator dan Gate Keeper, bekerjasama memproduksi konten bagi pendengar RRI Pro3.

Wawancara dengan Produser, mengurai konten media yang terdengar pada pesawat radio, terdiri dari siaran kata oleh penyiar dan siaran selain kata berupa musik atau lagu. Sifat auditif dalam konten ini mendorong tim produksi agar dapat memproduksi suara yang penulis istilahkan sebagai listenable content. Istilah ini berangkat dari argumentasi para tim produksi saat menyajikan informasi. Bagi seorang penyiar, siaran radio harus dapat dituturkan dengan vokal yang khas, artikulasi yang jelas, dan intonasi yang dinamis. Fokus penyajian konten bagi penyiar tertuju pada keterampilan olah vokal yang ditata dalam menuturkan berita.

Terkait dengan konten media yang disajikan, tim produksi dituntut mengelola konten yang informatif dan komunikatif. Informatif diartikan sebagai penyajian berita yang sesuai dengan kebutuhan dan keinginan pendengar, sedangkan komunikatif dinyatakan sebagai bentuk penyajian berita melalui pemilihan kata-kata yang tepat dan mudah dipahami. Selain itu, penyajian berita sebagai konten media juga turut dikemas dengan nuansa musik, backsound, bumper, smash dan 
sound effect yang tepat. Hal ini cukup mendasar dalam produksi konten radio auditif, mengingat satu-satunya perantara yang digunakan dalam mendistribusikan pesan adalah melalui audio semata.

Selama 2 (dua) jam penyajian konten dalam program Indonesia Menyapa, didominasi oleh siaran berita yang dituturkan penyiar sebagai siaran kata. Sapaan 'pendengar Pro3' kerap terdengar mengawali ucapan penyiar ketika membuka program acara. Sajian lagu nasional disajikan sesekali disela siaran berita yang padat. Kontribusi reporter dalam menyampaikan informasi dari berbagai lokasi dan komentar beberapa pendengar terkait topik hangat yang tengah diulas, terdengar pula sebagai pelengkap informasi yang dikelola menjadi satu kesatuan kemasan konten radio. Informasi yang padat, aktual dan faktual patut membangun konten media ini menjadi salah satu program yang unggul bagi para pendengarnya.

Pada tahapan ini, konten media tersaji sebagai media massa auditif. Seluruh aspek konten terdengar saling mendukung untuk menciptakan imajinasi pendengar, sehingga pesan yang disajikan menjadi menarik sekaligus informatif. Keunggulan radio sebagai medium komunikasi massa yang hanya bersumber pada suara, menjadikannya sebagai salah satu media yang dapat menemani kegiatan sehari-hari para pendengar. Menemani dapat diartikan sebagai media yang memproduksi konten untuk pendengar, sambil melakukan kegiatan lainnya. Konten dapat dinikmati sambil menyelesaikan pekerjaan di rumah, menghibur dalam perjalanan menuju tempat aktivitas, atau sebagai selingan ketika mengerjakan tugas di kantor.

\section{Konten Media sebagai Siaran Radio Visual}

Mengikuti perkembangan teknologi komunikasi ketika memasuki era media baru, konten RRI Pro3 pun tidak berjalan statis. Tekanan dalam memenuhi kebutuhan audiens yang dinamis, turut memicu dinamisasi konten berita yang tersaji. Perkembangan teknologi komunikasi sejak memasuki era media baru yang ditandai dengan hadirnya internet, terlihat membawa perubahan kemasan konten media.

Beradaptasi dengan fenomena perubahan yang terjadi, RRI melakukan inovasi melalui RRI Radio Visual. Mengusung tema "Tonton Apa yang Anda Dengar", diakui oleh Direktur Utama LPP RRI Mohammad Rohanudin untuk mengumpulkan publik di Indonesia. Kehadiran RRI Radio Visual ini, bukanlah ditujukan untuk bersaing dengan media televisi namun mengikuti pertumbuhan digitalisasi yang makin berkembang (www.rri. co.id).

Mengusung logo berlambang RRI Net, radio visual ini resmi diluncurkan bertepatan dengan hari jadinya ke-73, 12 September 2018. Menurut Rohanudin, RRI Net merupakan sebuah karakter radio yang divisualkan (www.antaranews.com).

Pernyataan di atas serupa dengan hasil pengamatan penulis, RRI Net merupakan digital platform sebagai alternatif media informasi berbentuk visualisasi konten auditif yang sebelumnya hanya terdengar. Platform ini dimanfaatkan oleh RRI dalam menyajikan berbagai konten yang diselenggarakan oleh empat programa (www.rri.co.id). Programa 1 (Pro1) - Pusat siaran pemberdayaan masyarakat, Programa 2 (Pro2) - Pusat siaran kreatifitas anak muda, Programa 3 (Pro 3) - Pusat siaran jaringan berita nasional dan kantor berita radio, dan Programa 4 (Pro 4) - Pusat siaran budaya dan pendidikan.

Program yang tersaji pada RRI Net dikelola pada pukul 06.00 - 24.00 WIB, merupakan gabungan dari konten yang terdapat pada 4 programa tersebut. Salah satu diantaranya adalah program Indonesia Menyapa. Program ini merupakan salah satu program unggulan yang juga ditayangkan RRI Net secara live atau siaran langsung dari studio RRI Pro3 selama 2 (dua) jam, yaitu pukul 07.00 - 09.00 WIB. Keterangan langsung dari Kasie Perencanaan Program dan Evaluasi Arita Mulat Kristianadewi, menyatakan bahwa program ini merupakan kemasan konten yang diperkuat sajian gambar, foto dan video menjadi satu kesatuan.

Ia menyatakan bahwa rundown dan flow program Indonesia Menyapa yang tayang secara on air di radio tidak mengalami perubahan. Melalui RRINet, kemasan konten yang disajikan merupakan bentuk 
visualisasi dari konten auditif yang dipancarkan melalui gelombang radio. Konvergensi teknologi komunikasi telah menyatukan media auditif dan media baru secara visual, sehingga konten media dapat dikonsumsi secara audio visual. Hal ini sejalan dengan ungkapan dari Direktur Utama LPP RRI, yakni menyajikan sebuah tontonan yang berasal dari konten radio. Artinya, inovasi yang dilakukan dalam menyajikan konten radio melalui radio visual di RRI Net, merupakan salah satu terobosan dalam mendistribusikan konten radio yang dapat dinikmati oleh telinga dan mata publiknya.

Konten radio visual dikemas dalam bentuk program yang tetap menjunjung karakteristik siaran radio. Bahasa tutur yang digunakan penyiar dalam menyampaikan pesan, tetap menjadi keutamaan bagi penyiar yang bertugas. Kemampuan olah vokal dalam mendistribusikan berita sebagai bentuk siaran kata juga masih melekat dalam diri seorang penyiar. Perubahan yang terjadi adalah penguatan konten radio dengan materi visual. Radio visual ini dapat diakses pada aplikasi RRI PLAY, XMedia, Usee TV, Ninmedia TV, dan RRI Net.

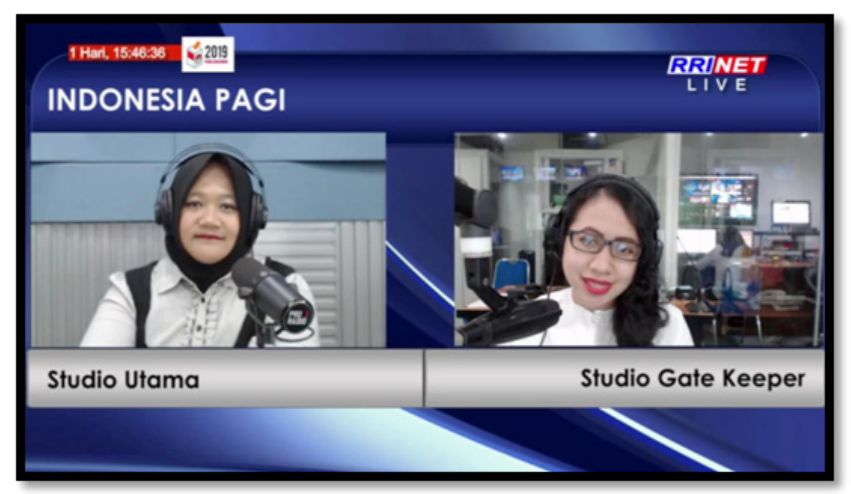

Gambar 1. Visualiasi Program Indonesia Menyapa di RRI Net

Sumber: Dokumentasi penulis

Berdasarkan pernyataan dari produser acara, terdapat beberapa konten visual di RRI Net. Platform ini menyajikan visualisasi penyiar dalam mendistribusikan konten. Sehingga untuk menyapa publiknya, penyiar menggunakan dua sapaan yaitu Pendengar RRI Pro3 dan Pemirsa RRI Net. Menariknya, setting studio on air untuk kebutuhan ini ditampilan secara alami untuk menggambarkan kegiatan siarannya. Penyiar tetap menggunakan headphone dan microphone studio radio layaknya keseharian operasional radio, berbeda dengan penyiar televisi yang biasanya menggunakan clip on mic wireless dan earpiece sebagai alat bantu di studio (gambar 1).

Visualisasi informasi reporter juga turut menghiasi variasi konten Indonesia Menyapa. Gimmick visual lain adalah informasi gate keeper yang menyampaikan komentar pendengar, sesuai topik saat itu. Visualisasi konten lainnya dari pengamatan penulis adalah tayangan lagu berbentuk video clip. Keterbatasan materi audio melalui gelombang radio sebelumnya, terkikis dengan platform radio visual ini. Kini pendengar radio layaknya menonton acara televisi dalam format konten radio.

Radio visual ini, berbentuk perubahan konten radio untuk telinga pendengar RRI Pro3, namun juga dinikmati visual oleh pemirsa RRI Net. Konten RRI Net, merupakan visualisasi konten radio yang telah ada dan berhasil menjadi program unggulan pendengar. Kebaruan konten bukan terletak pada konten yang didistribusikan, namun cara mengakses dan mengkonsumsi kontennya. Keberadaan media baru juga membantu perluasan distribusi konten Indonesia Menyapa. Gelombang radio yang menjangkau wilayah terbatas, menjadi borderless dengan platform RRI Net. Pada bahasan ini, siaran radio tetap memelihara kedekatan dengan pendengar atau pemirsanya dengan bahasa tutur yang digunakan.

\section{Konten Media sebagai Media Interaksi Visual}

Kehadiran radio visual yang diadaptasi dari konten radio sebelumnya, memunculkan peluang bentuk media komunikasi berikutnya. Keterampilan tim produksi RRI Pro3 menyajikan konten radio secara visual, melahirkan asumsi interaksi visual yang tidak hanya dapat dilakukan antara penyiar di studio dan tim produksi di luar studio. Di masa mendatang akan tercipta media baru yang menjembatani interaksi publik dengan pengelola konten.

Saat ini, interaksi dengan para pendengar RRI 
Pro3 dan pemirsa RRI Net dilakukan melalui aplikasi media sosial. Interaksi ini kemudian dituturkan oleh penyiar atau tim produksi yang bertugas secara on air. Visualisasi publik yang turut berinteraksi dalam konten ditayangkan dalam bentuk foto yang terdapat dalam profil pemilik akun. Cara lain dalam berinteraksi adalah melalui telepon studio yang disalurkan sebagai konten auditif saja.

Media interaksi seperti yang penulis uraikan di atas merupakan interaksi yang 'berjarak' antara publik dan penyiar. Hal ini tentunya lambat laun akan menurunkan konsep intimacy yang merupakan karakteristik dari media radio ini. Padahal perkembangan teknologi komunikasi merupakan sebuah bentuk adaptasi dari fenomena yang tampak di suatu masa. Melihat ketertarikan publik berinteraksi dengan para pengelola konten media, mengindikasikan sebuah kebutuhan dalam menghubungkan keduanya.

Berdasarkan karakteristik dan sifat media radio yang berkembang menjadi radio visual sebagai penguatan konten radio yang dapat ditonton, menciptakan sebuah pemahaman baru. Keakraban yang tercipta sebagai karakteristik media auditif di masa lalu dan pemanfaatan media baru dalam mengemas konten radio visual, diprediksi akan menjadikan konten media yang saat ini disajikan, akan menjadi media komunikasi baru di masa yang akan datang. Media komunikasi yang kelak akan makin melanggengkan keberadaan radio dalam industri media yang tidak akan tergerus media lainnya.

\section{Transformasi Konten Radio}

Penulis telah menguraikan pemahaman dalam mengamati perubahan bentuk media komunikasi di RRI Pro 3, khususnya dalam program Indonesia Menyapa. Program unggulan yang ditayangkan selama 2 (dua) jam pada pagi hari ini, tampak mengikuti perkembangan teknologi komunikasi. Dinamisasi dalam bentuk yang berbeda, namun menyimpan sifat dan karakteristik yang sama. Hal ini menguatkan landasan pemikiran Fidler dalam menjabarkan transformasi bentuk media komunikasi dalam konsep koevolusi pada teori mediamorfosis.

Konsep koevolusi yang penulis jadikan acuan dalam memahami fokus kajian dalam penelitian ini, menggaris bawahi sebuah bentuk komunikasi yang tersusun dalam sistem yang tidak dapat

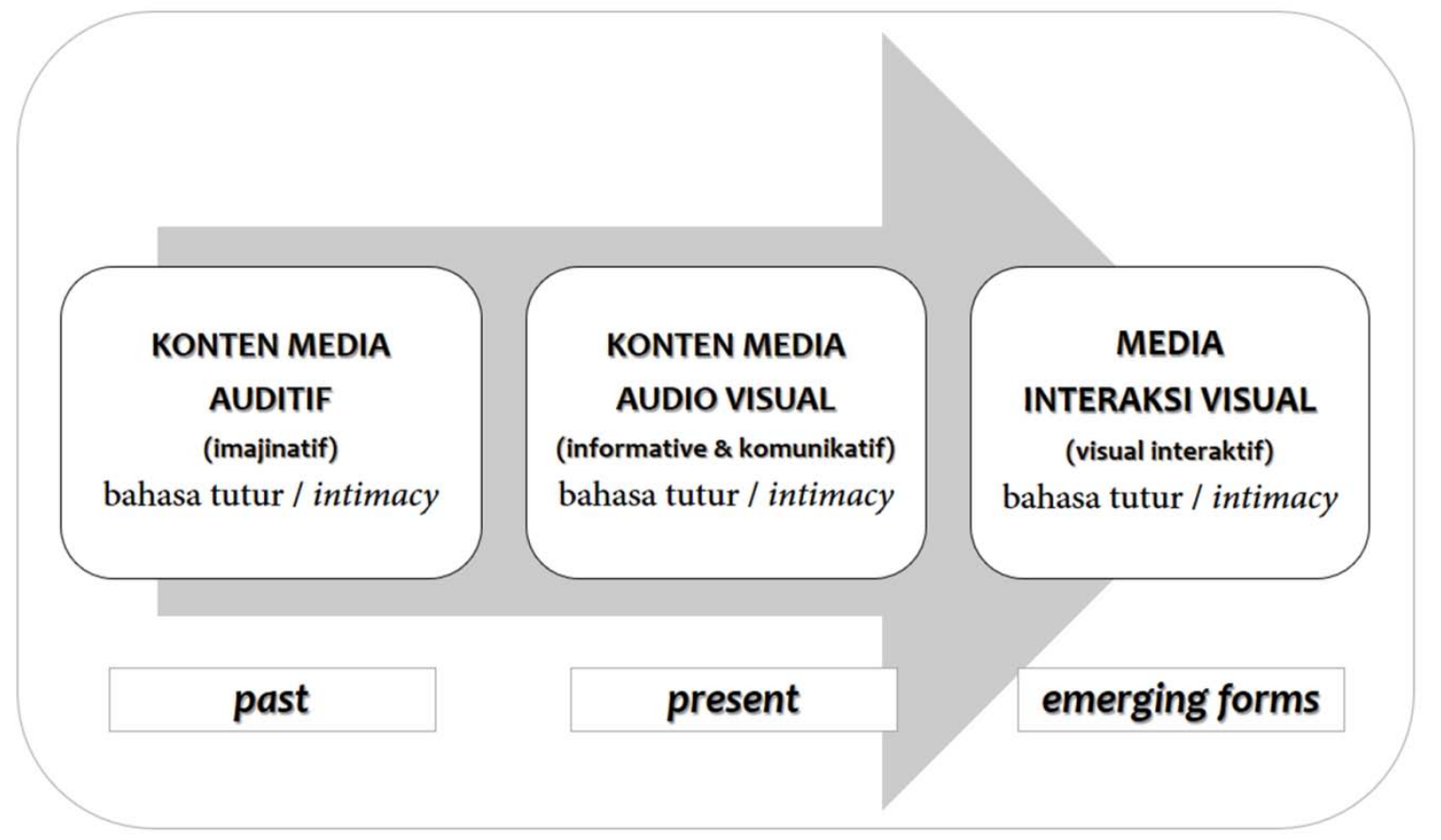

Gambar 2. Transformasi Konten Media

Sumber: Konstruksi Penulis berdasarkan Fidler (1997) 
dipisahkan satu sama lain. Kemunculan bentuk baru dalam suatu periode waktu tertentu hingga tingkatan yang beraneka ragam, akan memengaruhi perkembangan setiap bentuk lain yang ada. Hal ini pula yang penulis pahami dalam mengkonstruksi perubahan pada konten media di RRI Pro3.

Bentuk media komunikasi dalam menyajikan konten di masa lalu (past) berbentuk kreatifitas program auditif yang dikonsumsi telinga pendengar. Konten media yang bersumber pada suara didistribusikan melalui gelombang FM 88.8 MHz. Selanjutnya, perkembangan teknologi komunikasi yang diinisiasi oleh keberadaan internet memunculkan perubahan konten media. Pada tahap ini (present), dikemas konten auditif dengan penguatan konsep visual sehingga dapat dinikmati layaknya menonton tayangan televisi. Aplikasi yang terdapat pada berbagai saluran media baru, memunculkan RRI Net sebagai perubahan konten media yang diistilahkan dengan radio visual, dengan tagline "Tonton Apa yang Anda Dengar".

Transformasi konten media auditif menjadi radio visual, memberikan prediksi bentuk lainnya di masa yang akan datang (emerging forms). Prediksi berdasarkan pengamatan yang terurai dari perubahan di masa lalu dan tampak saat ini, mengasumsikan sebuah transformasi baru. Kemunculan konten media sebagai media komunikasi publik untuk berinteraksi dengan para pengelola media. Pemikiran ini tak lepas dari landasan kajian Fidler yang menuntut terciptanya sebuah bentuk perubahan di masa yang akan datang. Perubahan bentuk media yang tetap mewarisi sebagian besar sifat dasar spesies dalam sebuah siklus kehidupan. Dalam siaran radio, ciri yang tetap melekat adalah bahasa tutur untuk memelihara intimacy bagi khalayak media (gambar 2).

\section{SIMPULAN}

Fenomena perkembangan teknologi komunikasi memunculkan bentuk media komunikasi yang adaptif sesuai kebutuhan publik. Tuntutan media komunikasi yang dinamis dan kompetitif, memunculkan pemahaman perubahan dari masa ke masa. Konstruksi bentuk media terangkai sistematis sejak awal kemunculannya, keberadaannya saat ini, hingga prediksi bentuk di masa yang akan datang.

Landasan pemikiran Fidler pada konsep koevolusi dalam teori mediamorfosis, memicu konstruksi transformasi konten di RRI Pro3. Bentuk konten media di masa lalu bersumber pada materi auditif yang didistribusikan melalui gelombang FM 88.8 MHz. Konten media auditif ini dikenal sebagai media imajinatif.

Selanjutnya, perubahan teknologi komunikasi sejak era munculnya internet, memicu adaptasi dengan lingkungan sekitar. Kemasan RRI Net, dinamisasi konten media radio diperkuat dengan format visual saat ini, menciptakan alternatif bentuk konten yang informatif dan komunikatif.

Sajian konten media di masa lalu dan saat ini, memprediksi bentuk media komunikasi yang akan muncul di masa mendatang. Konten media bertransformasi dari bentuk auditif yang imajinatif, kemudian diperkuat menjadi konten radio visual, menggali pemikiran baru. Pemikiran akan munculnya konten media, bukan sebagai bentuk pesan yang diproduksi pengelola konten, namun sebagai media interaksi antara publik dan pengelola media. Sebuah bentuk media komunikasi yang diprediksi bertahan di masa yang akan datang.

Transformasi konten sebagai adaptasi perkembangan teknologi komunikasi, merupakan perubahan bentuk radio siaran. Namun bahasa tutur dalam memelihara intimacy dengan khalayak media merupakan ciri biologis yang menetap dalam setiap bentuk perubahan sesuai konsep koevolusi dalam teori mediamorfosis.

\section{DAFTAR PUSTAKA}

Ahern, Steve. (2011). Making Radio, A Practical Guide to Working in Radio in The Digital Age (3 ed.). 83 Alexander Street, Crows Nest NSW 2065, Australia: Allen \& Unwin.

Avilés, José. AG, and Carvajal, Miguel. (2008). Integrated and Cross-Media Newsroom Convergence. Two Models of Multimedia News Production - The Cases of 
Novotécnica and La Verdad Multimedia in Spain, The International Journal of Research into New Media Technologies, Vol. 14 No. 2, p: 221-239. DOI: $10.1177 / 1354856507087945$

Creswell, J. W. (2010). Research Design, Pendekatan Kualitatif, Kuantitatif, dan Mixed (cetakan 1) (Penerjemah: Achmad Fawaid). Yogyakarta: Pustaka Pelajar.

Crisel, A. (1994). Understanding Radio (Second Edition). 1 New Fetter Lane, London.: Routledge.

Denzin, N. K., \& Lincoln, Y. S. (2009). Handbook of Qualitative Research (penerjemah: Dariyatno dkk). Yogyakarta: Pustaka Pelajar.

Everette, D. E., \& Melvin L, D. (2010). Understanding Media in The Digital Age, Connection for Communication, Society and Culture. New York City: Pearson Education.

Fidler, R. (1997). Mediamorphosis, Understanding New Media. California 91320: Sage Publication.

Geller, V. (2011). Beyond Powerful Radio, A Communicator's Guide to The Internet Age (second edition). 30 Corporate Drive, Suite 400, Burlington, MA 01803, USA: Elsevier Limited.

Lynne, G., Brian, G., \& Philippe, P. (2005). Programming for TV, Radio \& The Internet, Second Edition: Strategy, Development \& Evaluation. 30 Corporate Drive, Suite 400,
Burlington, MA 01803, USA: Focal Press.

McQuail, D. (2011). Teori Komunikasi Massa (6th ed.) (Putri Iva Izzati, Trans). Jakarta: Salemba Humanika.

Morissan. (2008). Manajemen Media Penyiaran: Strategi Mengelola Radio \& Televisi. Edisi Pertama, Cetakan ke-1. Jakarta: Kencana Prenada Media Group.

Nwammuo, Angela Nkiru. (2011). Mediamorphosis: Analyzing the Convergence of Digital Media Forms Alongside African Traditional Media., African Research Review, An International Multi-Disciplinary Journal, Ethiopia, Vol. 5 No. 2, p. $115-125$.

Stanley J, B. (2019). Introduction to Mass Communication Media Literacy and Culture (10 ed.). New York, NY: McGrawHill Education.

Siahaan, Rony Agustino. (2016). Model Penyiaran dan Presentasi Siaran Berita Radio. Wacana Jurnal Ilmiah Ilmu Komunikasi, Vol. 15 No. 3, hlm. $226-231$.

Turow, J. (2014). Media Today, Mass Communication in A Converging World (Fifth edition). 711 3rd Avenue, New York, NY 10017.: Routledge .

Vivian, J. 2008. The Media of Mass Communication (8th Edition) (terjemahan:Tri Wibowo B.S). Jakarta: Kencana-Prenada Media Group.

http://rri.co.id/profil.html

https://www.antaranews.com/berita/747601/rriluncurkan-radio-visual 